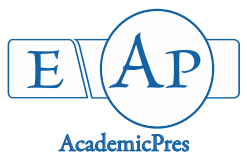

Sevindik E et al. (2021)

Notulae Scientia Biologicae

Volume 13, Issue 3, Article number 11034

DOI: $10.15835 / \mathrm{nsb} 13311034$

Research Article

\title{
Phylogenetic analysis of the genus Conringia Heist. Ex Fabr. (Brassicaceae) in Turkey based on nuclear (nrITS) and chloroplast (trnL-F) DNA sequences
}

\author{
Emre SEVINDIK ${ }^{1 *}$, Melike AYDOGAN ${ }^{1}$, Mehmet Y. PAKSOY ${ }^{2}$ \\ ${ }^{1}$ Adnan Menderes University, Faculty of Agriculture, Department of Agricultural Biotechnology, South Campus, Cakmar, Aydin, \\ Turkey; ph.d-emre@hotmail.com (*corresponding author);melikeaydogan95@gmail.com \\ ${ }^{2}$ Munzur University, Tunceli Vocational School, Department of Medical Services and Techniques, Medical Documentation and \\ Secretaryship Pr. Tunceli, Turkey; mypaksoy@gmail.com
}

\begin{abstract}
In this study, phylogenetic analysis of Turkish Conringia (Brassicaceae) species was conducted based on nuclear ribosomal DNA (nrITS) and chloroplast DNA (trnL-F) sequences. In addition, the relationships between the sequences of some Brassicaceae family species retrieved from NCBI, and Conringia species were documented. All of the plant specimens were collected at their flowering and vegetation periods from different regions of Turkey, and brought to the laboratory. Total genomic DNA was extracted using the GeneMark kit. In PCR analyses, ITS4 and ITS5A primers were used for the amplification of the nrITS region, while the trnLe and $t r n \mathrm{~L} f$ primers were used for the cpDNA trnL-F region. The DNA sequences obtained were then edited using BioEdit and FinchTV, and analyzed using MEGA 6.0 software. Neighbor joining (NJ) and bootstrap trees were constructed in order to identify the relationships among Conringia taxa. The nrITS sequences ranged between 573 and 672 nucleotides, while the trnL-F sequences ranged between 346 and 764 nucleotides. The divergence values of nrITS sequences differed between 0.177 and 0.00 and divergence values of $t r n \mathrm{~L}-\mathrm{F}$ sequences differed between 0.902 and 0.00 . NJ tree generated using nrITS and trnL-F sequences consisted of two clades. In trees generated with both the nrITS and trnL-F sequences, $C$. orientalis, $C$. grandiflora and $C$. austriaca appeared within the same group. In addition, according to the phylogenetic analysis results obtained with other Brassicaceae species, it is revealed that the Conringia genus is polyphyletic.
\end{abstract}

Keywords: Conringia, phylogenetic analysis; nrITS; trnL-F; Turkey

\section{Introduction}

The worldwide spread Brassicaceae family is a monophyletic group consisting of approximately 325 genera and over 3740 species. This cosmopolitan family has the highest diversity in the Western North America, Irano-Turanian region and the Mediterranean region (Bulbul et al., 2018; Bulbul et al., 2019). Turkey, the second richest country after the United States in terms of the Brassicaceae taxa, contains 91 genera and 686 species (Yılmaz-Çıtak and Dural, 2020; Dönmez et al., 2021). Agronomically important Brassicaceae family also includes many economically important edible and industrial oilseeds, vegetables, flavors, spices,

Received: 21 Jul 2021. Received in revised form: 22 Aug 2021. Accepted: 02 Sep 2021. Published online: 07 Sep 2021.

From Volume 13, Issue 1, 2021, Notulae Scientia Biologicae journal uses article numbers in place of the traditional method of continuous pagination through the volume. The journal will continue to appear quarterly, as before, with four annual numbers. 
ethnobotanically and fodder plants (Koch et al., 2001; Ahmed et al., 2012; Polat et al., 2017; Gidik et al., 2019; Kawarty et al., 2020). The most important edible oil plant is Brassica napus L. known as canola or oil turnip, while Sinapis alba L. and Brassica nigra (L.) Koch seeds are also used. Spice plants include Brassica juncea (L.) Czern, Armoracia rusticana (Lam.) Gaertner, Mey. Et Schreb., and Erysimum L. species (Sirali et al., 2013). This family also includes Arabidopsis thaliana (L.) Heynh. which is a well-known model species in plant biology (Couvreur et al., 2010; Özüdoğru et al., 2017). Conringia Heist. Ex Fabr. is a Brassicaceae genus containing annual taxa with 6 species in Turkey. These species are; C. grandiflora Boiss. \& Heldr., C. orientalis (L.) Dumort., C. planisiliqua Fisch. \& Mey, C. persica Boiss., C. austriaca (Jacq.) Sweet, Hort. and C. clavata (C. A. Mey.) Busch. Of these 6 taxa, $C$. grandiflora is endemic with an endemism rate of $17 \%$. C. clavata is not included in the Flora of Turkey (Hedge 1965) because the taxa of this species are known as C.perfoliata in the first volume of this book (Al-Shehbaz et al., 2007; Selvi et al., 2019).

Molecular phylogenetics has provided a new vision for understanding the origin of land plants, elucidating the relationships among them, and reconstructing phylogenetic history (Khan et al., 2016). The ITS region of nuclear ribosomal DNA ( $\mathrm{nrDNA}$ ) is one of the most popular and effective genetic markers for inferring phylogenetic relationships and evolutionary studies in plants. Due to its high species distinction, technical amplification convenience, and high primer universality, it has been used in various organisms at genus and species levels (Sun et al., 2012; Guo et al., 2016; Demir et al., 2020). In particular, ITS regions that are characterized by parental inheritance patterns develop more rapidly than coding regions, leading to higher levels of variation among closely related individuals (Najarian et al., 2020). Advances in DNA sequence techniques have allowed the widespread use of short DNA fragments, particularly from the chloroplast genome, in phylogenetic relationships studies (Penjor et al., 2010). Chloroplast DNA (cpDNA) regions are widely used for phylogenetic studies at all taxonomic levels (Drabkova et al., 2004). $\operatorname{trnL}$ - $\operatorname{trnF}$, one of these regions, is preferred for intra and interspecific levels in plants (Kaya et al., 2018).

In this study, sequence analyses of Turkish Conringia taxa using nrITS and cpDNA trnL-F sequences were performed to elucidate phylogenetic relationships among the ingroup taxa. In addition, Boreava orientalis (GQ131309.1, DQ518353.1), Isatis tinctoria (KF022713.1, KJ765846.1), Fibigia clypeata (KF022650.1, KM033543.1), Lepidium ruderale (KJ623529.1, KJ623450.1), Sisymbrium altissimum (HQ896628.1, AY958545.1), Arabis montbretiana (KF547279.1, KF547548.1), Hesperis matronalis (DQ357547.1, AY546166.1), Alyssoides utriculata (KF022512.1, KM033540.1), Alyssum linifolium (KJ623478.1, KJ623461.1), Brassica cretica (GQ268075.1, Y15350.1), Brassica deflexa (GQ268077.1, GQ268052.1), Calepina irregularis (DQ249822.1, AY751760.1) and Goldbachia laevigata(DQ357546.1, KJ623408.1) were compared with Conringia species with respect to both nrITS and trnL-F sequences, after retrieving their sequence data from NCBI nucleotide database.

\section{Materials and Methods}

\section{Plant samples and DNA isolations}

The study materials included the specimens of Conringia grandiflora, C. orientalis, C. persica, $C$. austriaca, $C$. perfoliata and C.planisiliqua species. The collected specimens, by looking at the identification key from Flora of Turkey were identified by Dr. Mehmet Yavuz PAKSOY. All specimens and the locations they are collected from are presented in Table 1. Conringia species were brought to the laboratory, some of them were used for genomic DNA isolation and some of them were preserved as herbarium specimens. For genomic DNA isolation, a commercial kit (GeneMark Catalog No: DP022) was used. 
Table 1. Location of Conringia species in Turkey

\begin{tabular}{|c|c|c|c|}
\hline Taxa & Location & $\begin{array}{c}\text { GenBank No } \\
\text { (nrITS) }\end{array}$ & $\begin{array}{c}\text { GenBank No } \\
(\text { trnL-F })\end{array}$ \\
\hline $\begin{array}{l}\text { Conringia perfoliata } \\
\text { (Yıldizeli) }\end{array}$ & $\begin{array}{c}\text { TURKEY/Sivas; Yıldızeli, Kümbet } \\
\text { village, step, } 1500 \text { m, 15.05.2014, } \\
\text { MY143 }\end{array}$ & MZ723114 & MZ726898 \\
\hline $\begin{array}{l}\text { Contingia perfoliata } \\
\text { (Ankara Ayaş) }\end{array}$ & $\begin{array}{c}\text { TURKEY/Ankara; Ayaş- Beypazarı, } \\
\text { Akkaya village, } 650 \mathrm{~m}, 19.05 .2014, \\
\text { MY152 }\end{array}$ & MZ723103 & MZ726899 \\
\hline $\begin{array}{l}\text { Conringia perfoliata } \\
\text { (Kayseri) }\end{array}$ & $\begin{array}{l}\text { TURKEY/Kayseri; Pınarbaşı, Şirvan } \\
\text { mountain southern slopes, mountain } \\
\text { steppe, } 1700 \mathrm{~m}, 16.05 .2014 \text {, MY146 }\end{array}$ & MZ723115 & MZ726900 \\
\hline $\begin{array}{l}\text { Conringia grandiflora } \\
\text { (Akseki Çukurköy) }\end{array}$ & $\begin{array}{l}\text { TURKEY/Antalya; Akseki, between } \\
\text { Murtiçi and Çukurköy, maquis span, } \\
500 \mathrm{~m}, 21.03 .2014, \text { MY136 }\end{array}$ & MZ734227 & MZ726895 \\
\hline $\begin{array}{l}\text { Conringia grandiflora } \\
\text { (Alanya) }\end{array}$ & $\begin{array}{l}\text { TURKEY/Antalya: Alanya, } \\
\text { Hacımahmetli village, field side, 150- } \\
200 \text { m, 21.03.2014, MY138 }\end{array}$ & MZ734230 & MZ726896 \\
\hline $\begin{array}{l}\text { Conringia planisiliqua } \\
\text { (Kırşehir) }\end{array}$ & $\begin{array}{c}\text { TURKEY/Kırşehir;İnanç village } \\
\text { opposite, Üçkuyu back, rocky places, } \\
1450 \mathrm{~m}, 17.05 .2014, \mathrm{MY} 120\end{array}$ & MZ723083 & MZ726887 \\
\hline $\begin{array}{l}\text { Conringia planisiliqua } \\
\text { (Bunyan) }\end{array}$ & $\begin{array}{c}\text { TURKEY/Kayseri; Bunyan, } \\
\text { Korumaz mountain, Bölünya } \\
\text { locality, field edge, } 1500 \mathrm{~m}, \\
\text { 16.05.2014, MY147 }\end{array}$ & MZ723084 & MZ726889 \\
\hline $\begin{array}{l}\text { Conringia planisiliqua } \\
\text { (Sivas) }\end{array}$ & $\begin{array}{c}\text { TURKEY/Sivas- Zara road, Tödürge } \\
\text { lake edge, } 1300 \mathrm{~m}, 15.05 .2014, \\
\text { MY144. }\end{array}$ & MZ723087 & MZ726888 \\
\hline $\begin{array}{l}\text { Conringia planisiliqua } \\
\text { (Nallıhan-Çayırhan) }\end{array}$ & $\begin{array}{c}\text { TURKEY/Ankara: Between } \\
\text { Çayırhan and Nallihan, step, } 650 \mathrm{~m} \text {, } \\
\text { 19.05.2014, MY149 }\end{array}$ & MZ723086 & MZ726891 \\
\hline $\begin{array}{l}\text { Conringia planisiliqua } \\
\text { (Ankara Ayaş) }\end{array}$ & $\begin{array}{c}\text { TURKEY/Ankara; Ayaş- Beypazarı, } \\
\text { Akkaya village, } 700 \text { m, 19.05.2014, } \\
\text { MY151 }\end{array}$ & MZ723079 & MZ726890 \\
\hline Conringia persica (Van) & $\begin{array}{c}\text { TURKEY/Van: between Van- } \\
\text { Başkale, Çuh passage, steppe, } 2500 \\
\text { m, 29.05.2013, MY141 }\end{array}$ & MZ734229 & MZ726897 \\
\hline Conringia austriaca (Adana) & $\begin{array}{c}\text { TURKEY/Adana: Kozan, Gürümze } \\
\text { village upper sections, forest } \\
\text { clearance, } 1350 \mathrm{~m}, 18.04 .2014 \text {, } \\
\text { MY142 }\end{array}$ & MZ734226 & MZ726894 \\
\hline $\begin{array}{l}\text { Conringia orientalis (Ankara } \\
\text { Polatlı) }\end{array}$ & $\begin{array}{c}\text { TURKEY/Ankara: Polatli, Kavuncu } \\
\text { bridge near, swamp places, } 850 \mathrm{~m} \text {, } \\
\text { 19.05.2014, MY150 }\end{array}$ & MZ723094 & MZ726893 \\
\hline Conringia orientalis (Elazığ) & $\begin{array}{c}\text { TURKEY/Elazig; Between Keban } \\
\text { and Elazig, } 5 \mathrm{~km} \text {, steppe, } 850 \mathrm{~m} \text {, } \\
\text { 13.05.2014, MY126 }\end{array}$ & MZ723092 & MZ726892 \\
\hline
\end{tabular}

\section{PCR Amplifications and Sequencing}

We amplified DNA of the nrITS and trnL-F regions of each genomic DNA. Amplification of nrITS region was performed using primers ITS5A (designed by Kenneth Wurdack) and ITS4 (White et al., 1990) and trnL-F amplifications were performed using the primers designed by Taberlet et al. (1991). Both PCR 
components and programs for nrITS and trnL-F region are given in Table 2. Gel electrophoresis in $0.1 \%$ agarose gel run in 10X Tris- Boric EDTA buffer was used to size fractionate amplicons. Subsequently, gels were stained with ethidium bromide and visualized over a UV trans-illuminator. ITS4 and ITS5A primers (for nuclear sequences) and trnLe and $t r n F f$ primers (for chloroplast sequences) were used both for amplification and for sequencing which were conducted at TRIOGEN (İstanbul, Turkey). For each sample, forward and reverse sequencing reactions were performed and the sequences were analyzed via GenBank (NCBI) through (Basic Local Alignment Search Tool) BLASTn search. Later obtained DNA sequences were edited both manually and by using Bioedit (Hall, 1999) and FinchTV programs. Both nrITS and trnL-F sequences were uploaded into NCBI and GenBank numbers are given in Table 1.

Table 2. nrITS and cpDNA trnL-F primers and PCR components used for PCR amplification

\begin{tabular}{|c|c|c|c|}
\hline Primer name & 5' to 3' Primer sequence & PCR components & PCR amplification (35 cycle) \\
\hline$\frac{\text { Forward }}{\text { ITS5A }}$ & ССTTATCATTTAGAGGAAGGAG & \multirow{4}{*}{$\begin{array}{c}1 \mu \mathrm{L} \text { genomic DNA } 1 \\
\mu \mathrm{L} \text { primer (forward), } 1 \\
\mu \mathrm{L} \text { primer (reverse), } 5 \\
\mu \mathrm{L} \text { master mix (PCR } \\
\text { buffer, } 2 \mathrm{Mm} \mathrm{MgCl}_{2}, \\
\mathrm{dNTP}, 0.75 \mathrm{U} \mathrm{Taq} \\
\text { DNA polymerase) and } \\
17 \mu \mathrm{L} \mathrm{dH}_{2} \mathrm{O}\end{array}$} & \multirow{4}{*}{$\begin{array}{c}94^{\circ} \mathrm{C} / 4 \mathrm{~min} \\
94^{\circ} \mathrm{C} / 1 \mathrm{~min} \\
50^{\circ} \mathrm{C} / 1 \mathrm{~min} \\
72^{\circ} \mathrm{C} / 1 \mathrm{~min} \\
72^{\circ} \mathrm{C} / 10 \mathrm{~min} .\end{array}$} \\
\hline$\frac{\text { Reverse }}{\text { ITS } 4}$ & TCCTCCGCTTATTGATATGC & & \\
\hline$\frac{\text { Forward }}{\text { trnLe }}$ & GGTTCAAGTCCСTCTATCCC & & \\
\hline$\frac{\text { Reverse }}{\text { trnFf }}$ & ATTTGAACTGGTGACACGAG & & \\
\hline
\end{tabular}

\section{Phylogenetic analysis}

The phylogenetic tree was generated using the Neighbor joining (NJ) method (Saitou and Nei, 1987) and constructed using MEGA 6.0 software (Tamura et al., 2013). The phylogenetic tree was evaluated with bootstrap test on 1000 resampling's (Felsenstein, 1985). Also, the genetic distance matrix between the species was also performed using the same software.

\section{Results and Discussion}

In recent years, many PCR based molecular markers such as nrDNA ITS, RAPD and ISSR markers have been developed and tested in genetic studies of various organisms among populations (Poyraz, 2016). The nrITS sequences obtained in this study ranged from 573 to 672 nucleotides among 14 samples. The highest nucleotide number for the nrITS sequence was recorded for $C$. perfoliata (Y1ldizeli) (672 bases), and the lowest number of nucleotides for the nrITS sequence was observed in $C$. orientalis (Elazığ) ( 573 bases). The average nucleotide composition of nrITS was $21.4 \% \mathrm{~T}, 28.9 \% \mathrm{C}, 22.8 \% \mathrm{~A}$, and $26.8 \% \mathrm{G}$. The total length of the aligned nrITS sequence matrix was found to be 691 nucleotides. While the highest genetic distance between the species was 0.177 , the lowest was found to be 0.000 (Table 3). NJ tree created with nrITS sequences consisted of two clades (Figure 1). Clade 1 is divided into two subclades within itself. Subclade A consisted of C. planisiliqua populations collected from different localities and received 100\% bootstrap support. Subclade B, C. perfoliata populations, and $C$. persica species emerged as a monophyletic group with a bootstrap value of 99\%. Clade 2 is divided into 2 subclades within itself. Subclade A was composed of $C$. grandiflora (Akseki) and C. grandiflora (Alanya) populations and received support with a bootstrap value of $99 \%$. Subclade B consisted of $C$. orientalis populations and C. austriaca species and received a bootstrap support of $98 \%$. nrITS analysis indicated that the populations belonging to the species came out in the same group. The $\operatorname{trn} \mathrm{L}^{(\mathrm{UAA})}-\operatorname{trn} \mathrm{F}^{\text {(GAA) }}$ intergenic spacer (IGS) encoding transfer RNAs for leucine and phenylalanine is widely used for phylogenetic analysis of intraspecific variations in plants (Türktaş et al., 2012; Filiz et al., 2018). For the trnL-F sequences, the length ranged from 346 to 769 nucleotides among 14 samples. For $t r n \mathrm{~L}-\mathrm{F}$ sequences, the highest nucleotide number was observed in C. grandiflora (Alanya) (769 bases), and the lowest number of nucleotides was 
observed in $C$. persica (346 bases). The average nucleotide composition of $t r n \mathrm{~L}-\mathrm{F}$ was $33.1 \%$ T, $19.1 \mathrm{C}, 29.3 \%$ $\mathrm{A}$, and $18.6 \% \mathrm{G}$. The total length of the aligned $t r n \mathrm{~L}-\mathrm{F}$ sequence matrix was found to be 830 nucleotides. The highest genetic distance between species was found to be 0.902 , while the lowest was 0.000 (Table 4).

Table 3. Pairwise genetic distance matrix obtained from nrITS sequences

\begin{tabular}{|c|c|c|c|c|c|c|c|c|c|c|c|c|c|}
\hline $\begin{array}{l}\text { C.orientalis } \\
\text { (Elazig) }\end{array}$ & - & & & & & & & & & & & & \\
\hline $\begin{array}{l}\text { C.orientalis } \\
\text { (Ankara) }\end{array}$ & 0.081 & & & & & & & & & & & & \\
\hline $\begin{array}{l}\text { C.austrica } \\
\text { (Adana) }\end{array}$ & 0.094 & 0.081 & & & & & & & & & & & \\
\hline $\begin{array}{l}\text { C.grandiflora } \\
\text { (Akseki) }\end{array}$ & 0.085 & 0.047 & 0.068 & & & & & & & & & & \\
\hline $\begin{array}{l}\text { C.grandiflora } \\
\text { (Alanya) }\end{array}$ & 0.085 & 0.047 & 0.068 & 0.000 & & & & & & & & & \\
\hline $\begin{array}{l}\text { C.perfoliata } \\
\text { (Ankara) }\end{array}$ & 0.158 & 0.118 & 0.138 & 0.102 & 0.102 & & & & & & & & \\
\hline $\begin{array}{l}\text { C.perfoliata } \\
\text { (Kayseri) }\end{array}$ & 0.158 & 0.118 & 0.138 & 0.102 & 0.102 & 0.000 & & & & & & & \\
\hline $\begin{array}{l}\text { C.perfoliata } \\
\text { (Y1ldzeli) }\end{array}$ & 0.158 & 0.118 & 0.138 & 0.102 & 0.102 & 0.000 & 0.000 & & & & & & \\
\hline $\begin{array}{l}\text { C. planisiliqua } \\
\text { (Ankara) }\end{array}$ & 0.177 & 0.135 & 0.158 & 0.107 & 0.107 & 0.152 & 0.152 & 0.152 & & & & & \\
\hline $\begin{array}{l}\text { C planisiliqua } \\
\text { (Kirsehir) }\end{array}$ & 0.177 & 0.135 & 0.158 & 0.107 & 0.107 & 0.152 & 0.152 & 0.152 & 0.000 & & & & \\
\hline $\begin{array}{l}\text { C. planisiliqua } \\
\text { (Bunyan) }\end{array}$ & 0.177 & 0.135 & 0.158 & 0.107 & 0.107 & 0.152 & 0.152 & 0.152 & 0.000 & 0.000 & & & \\
\hline $\begin{array}{l}\text { C. planisiliqua } \\
\text { (Nallıhan) }\end{array}$ & 0.177 & 0.135 & 0.158 & 0.107 & 0.107 & 0.152 & 0.152 & 0.152 & 0.000 & 0.000 & 0.000 & & \\
\hline $\begin{array}{l}\text { C. planisiliqua } \\
\text { (Sivas) }\end{array}$ & 0.177 & 0.135 & 0.158 & 0.107 & 0.107 & 0.152 & 0.152 & 0.152 & 0.000 & 0.000 & 0.000 & 0.000 & \\
\hline C.persica (Van) & 0.126 & 0.083 & 0.105 & 0.064 & 0.064 & 0.066 & 0.066 & 0.066 & 0.114 & 0.114 & 0.114 & 0.114 & 0.114 \\
\hline
\end{tabular}

Table 4. Pairwise genetic distance matrix obtained from cpDNA trnL-F sequences

\begin{tabular}{|c|c|c|c|c|c|c|c|c|c|c|c|c|c|}
\hline $\begin{array}{l}\text { C.austrica } \\
\text { (Adana) }\end{array}$ & - & & & & & & & & & & & & \\
\hline $\begin{array}{l}\text { C. planisiliqua } \\
\text { (Ankara) }\end{array}$ & 0.083 & & & & & & & & & & & & \\
\hline $\begin{array}{l}\text { C. planisiliqua } \\
\text { (Nallıhan) }\end{array}$ & 0.083 & 0.000 & & & & & & & & & & & \\
\hline $\begin{array}{l}\text { C. planisiliqua } \\
\text { (Sivas) }\end{array}$ & 0.083 & 0.000 & 0.000 & & & & & & & & & & \\
\hline $\begin{array}{l}\text { C.orientalis } \\
\text { (Ankara) }\end{array}$ & 0.017 & 0.063 & 0.063 & 0.063 & & & & & & & & & \\
\hline $\begin{array}{l}\text { C.grandiflora } \\
\text { (Akseki) }\end{array}$ & 0.022 & 0.059 & 0.059 & 0.059 & 0.004 & & & & & & & & \\
\hline $\begin{array}{l}\text { C.persica } \\
\text { (Van) }\end{array}$ & 0.892 & 0.811 & 0.811 & 0.811 & 0.837 & 0.819 & & & & & & & \\
\hline $\begin{array}{l}\text { C.perfoliata } \\
\text { (Ankara) }\end{array}$ & 0.902 & 0.852 & 0.852 & 0.852 & 0.847 & 0.862 & 0.044 & & & & & & \\
\hline $\begin{array}{l}\text { C.perfoliata } \\
\text { (Kayseri) }\end{array}$ & 0.902 & 0.852 & 0.852 & 0.852 & 0.847 & 0.862 & 0.044 & 0.000 & & & & & \\
\hline $\begin{array}{l}\text { C.perfoliata } \\
\text { (Yildizeli) }\end{array}$ & 0.902 & 0.852 & 0.852 & 0.852 & 0.847 & 0.862 & 0.044 & 0.000 & 0.000 & & & & \\
\hline $\begin{array}{l}\text { C.grandiflora } \\
\text { (Alanya) }\end{array}$ & 0.026 & 0.054 & 0.054 & 0.054 & 0.009 & 0.004 & 0.831 & 0.875 & 0.875 & 0.875 & & & \\
\hline $\begin{array}{l}\text { C. planisiliqua } \\
\text { (Bunyan) }\end{array}$ & 0.078 & 0.004 & 0.004 & 0.004 & 0.059 & 0.063 & 0.829 & 0.837 & 0.837 & 0.837 & 0.059 & & \\
\hline $\begin{array}{l}\text { Cplanisiliqua } \\
\text { (Kirsehir) }\end{array}$ & 0.083 & 0.000 & 0.000 & 0.000 & 0.063 & 0.059 & 0.811 & 0.852 & 0.852 & 0.852 & 0.054 & 0.004 & \\
\hline $\begin{array}{l}\text { C.orientalis } \\
\text { (Elazig) }\end{array}$ & 0.017 & 0.063 & 0.063 & 0.063 & 0.000 & 0.004 & 0.837 & 0.847 & 0.847 & 0.847 & 0.009 & 0.059 & 0.063 \\
\hline
\end{tabular}


NJ phylogenetic tree created with cpDNA trnL-F sequences consisted of two clades (Figure 2).

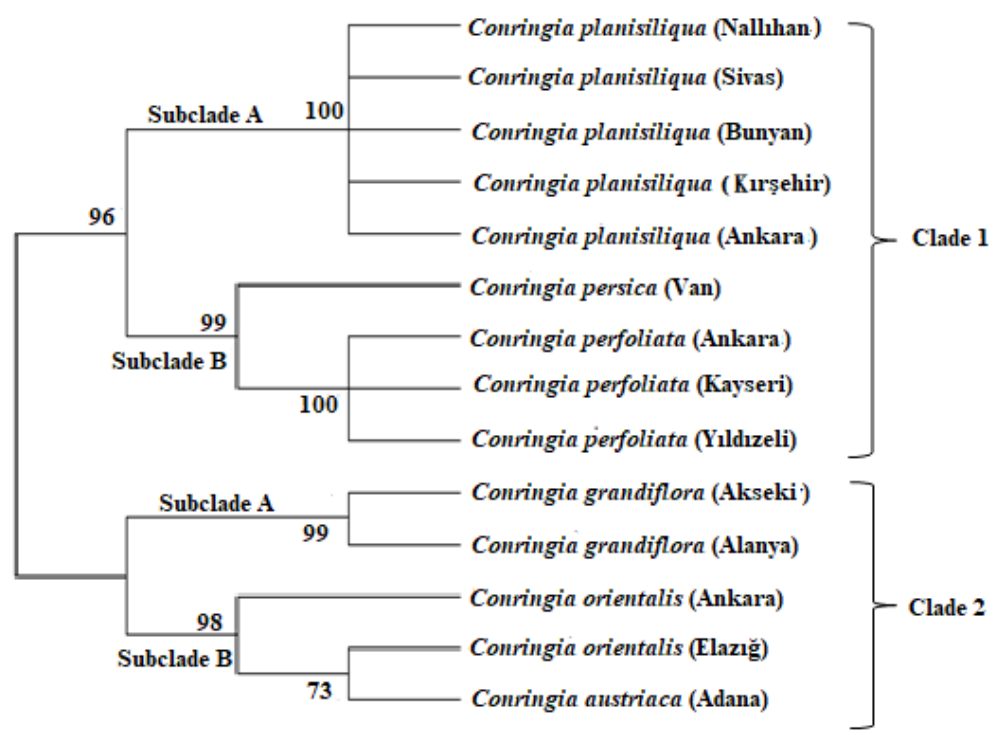

Figure 1. The Neighbour joining tree generated using nrITS sequences Conringia genus (Bootstrap values greater than $50 \%$ are given above branches)

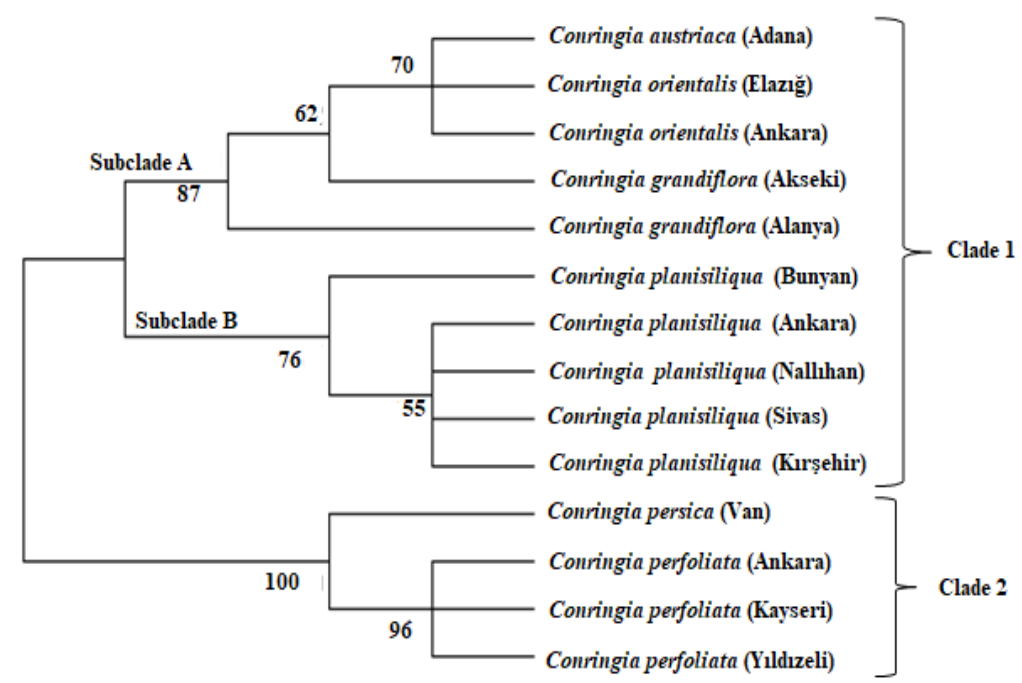

Figure 2. The Neighbour joining tree generated using cpDNA trnL-F sequences Conringia genus (Bootstrap values greater than $50 \%$ are given above branches)

Clade 1 is divided into two subclades within itself. Subclade A is composed of C. austriaca, C. orientalis, and C.grandiflora species and was supported with a bootstrap value of $87 \%$. Subclade B consisted of C. planisiliquapopulations and was supported by a $76 \%$ bootstrapped value. Clade 2 consisted of C. perfoliata and C. persica species. This clade is supported by a $100 \%$ bootstrap value. When we compare the

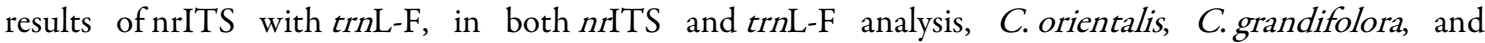
C. austriaca were found to be in the same clade. Similarly, C. perfoliata and C.persica species also emerged together. However, in the nrITS results, while $C$. planisiliqua populations were found to be in Clade 1 with $C$. persica and $C$. perfoliata species; in trnL-F analyzes, $C$. planisiliqua populations were found to be in clade 1 
with C. orientalis, C. austriaca and C. grandiflora. C. perfoliata and C. persica species were found to be in clade 2. Sevindik et al. (2020) revealed the genetic variation and molecular relationship of Conringia species in Turkey using RAPD markers. According to the RAPD results, C.perfoliatapopulations and C. grandiflora (Akseki-Çukurköy) species were found in a clade. In our nrITS results, while C. perfoliata and C. persica species were found to be in Clade 1, and together with $C$. persica species, $C$. grandiflora appeared in the same group with $C$. orientalis in Clade 2. In trnL-F results, $C$. grandiflora were found to be in the same group as C. orientalis, while C.perfoliata populations appeared in Clade 2 with C.persica species. In RAPD analyzes, $C$. orientalis, $C$. planisiliqua, $C$. austriaca, and $C$. persica were found to be in the same clade. In nrITS results, while C.orientalis, C.austriaca, and $C$. grandiflora species were found to be in Clade 2 and $C$. planisiliqua populations in Clade 1. According to trnL-F analyses, $C$. orientalis, C. austriaca, C. grandiflora, and C.planisiliquaspecies appeared in Clade 1. Selvi et al. (2019) studied the micromorphological and anatomical characters to contribute to the systematic structure of the genus Conringia in Turkey. In the study, root, stem and leaf anatomy along with stem and leaf surfaces of the species were examined with micromorphological studies. Leaf and stem anatomies of $C$. austriaca and C.persica and C. orientalis and C. planisiliqua species were found to be close to each other. In the nrITS and trnL-F results, C. austriaca and C. persica appeared in different groups. While $C$. orientalis and $C$. planisiliqua species appeared in different groups in nrITS results, they were found to be in the same group according to trnL-F results. While the results were inconsistent with the nrITS results, they were consistent with the trnL-F results.

In our study, phylogenetic relationships of some taxa (belonging to Brassicaceae family whose nrITS and trnL-F sequences were retrieved from NCBI) with Conringia species have been revealed. In nrITS results, while C. perfoliata, C. orientalis, C. austriaca, C. grandiflora, and C. persica species were included in the same clade, populations of $C$. planisiliqua species were included in a different clade. According to the nrITS results, the genus Conringia is a polyphyletic species. According to cpDNA trnL-F analysis, C. planisiliqua, C. orientalis, C. grandiflora, and C. austriaca species are included in Clade 1, while C.perfoliata and C. persica species are included in Clade 2. Liu et al. (2012) revealed the phylogenetic relationship of Brassicaceae species by cpDNA matK sequence analysis. They found that C.planisiliquawas in the same group with Isatis minima and Isatis tinctoria. Zhao et al. (2010) revealed the phylogenetic relationships of species belonging to the Brassicaceae family by sequence analysis of chalcone synthase (chs) genes. Their study also revealed that $C$. planisiliqua was a sister species with Isatis tinctoria and Pachypterygium multicaule. Koch et al. (2007) revealed that C. planisiliqua emerged in a sister group with Isatis tinctoria and Boreava orientalis in their Plastid trnL intron and trnL-F intergenic spacer sequences analysis. In both nrITS and trnL-F sequence analysis we performed, C. planisiliqua populations, Isatis tinctoria and Boreava orientalis were found in the same group. Our results support the studies by Liu et al. (2012), Zhao et al. (2010) and Koch et al. (2007). Warwick and Sauder, (2005) performed the phylogenetic analysis of the Brassiceae tribe using chloroplast restriction site polymorphisms and nuclear ribosomal ITS and chloroplast $t r n \mathrm{~L}$ intron sequences. According to the trnL intron and chloroplast restriction site polymorphism results of the study, C. orientalis and C. perfoliata species were found to be in the same group. In our study, these two species are included in Clade 2, according to the nrITS results (Figure 3). In the trnL-F results, C. orientalis was included in Clade 1 and C. perfoliata in Clade 2 (Figure 4). In addition, as a result of ITS, trnL intron, and chloroplast restriction site polymorphisms, C. orientalis and C. perfoliata species were found to coexist with Calepina irregularis. In our study, according to the ITS results, Calepina irregularis is separated from C.orientalis, and C.perfoliata and C. planisiliquawere included in Clade 1. In trnL-F results, Calepina irregularis, C. orientalis, and C. planisiliqua were included in Clade 1, while C. perfoliata was included in Clade 2. Khosravi et al. (2009) performed the phylogenetic analysis of the Brassicaceae family with nrDNA ITS sequences. According to nrDNA ITS results, Conringia perfoliata, Conringia orientalis, and Conringia persica species were in the same group. Their study revealed that C.planisiliqua and Orychophragmus violaceus species were found to be related to Isatis and Tauscheria. In our nrITS results, while $C$. perfoliata, $C$. orientalis, and $C$. persica species were found to be in clade 2, C. planisiliqua is related with Boreava orientalis and Isatis tinctoria in clade 1 
(Figure 3). According to trnL-F results, while C. orientalis and C. persica species were found to be in Clade 1, C. persica was found to be in Clade 2. Similarly, C. planisiliqua was found to be in Clade 1, in the same group as Boreava orientalis and Isatis tinctoria (Figure 4).

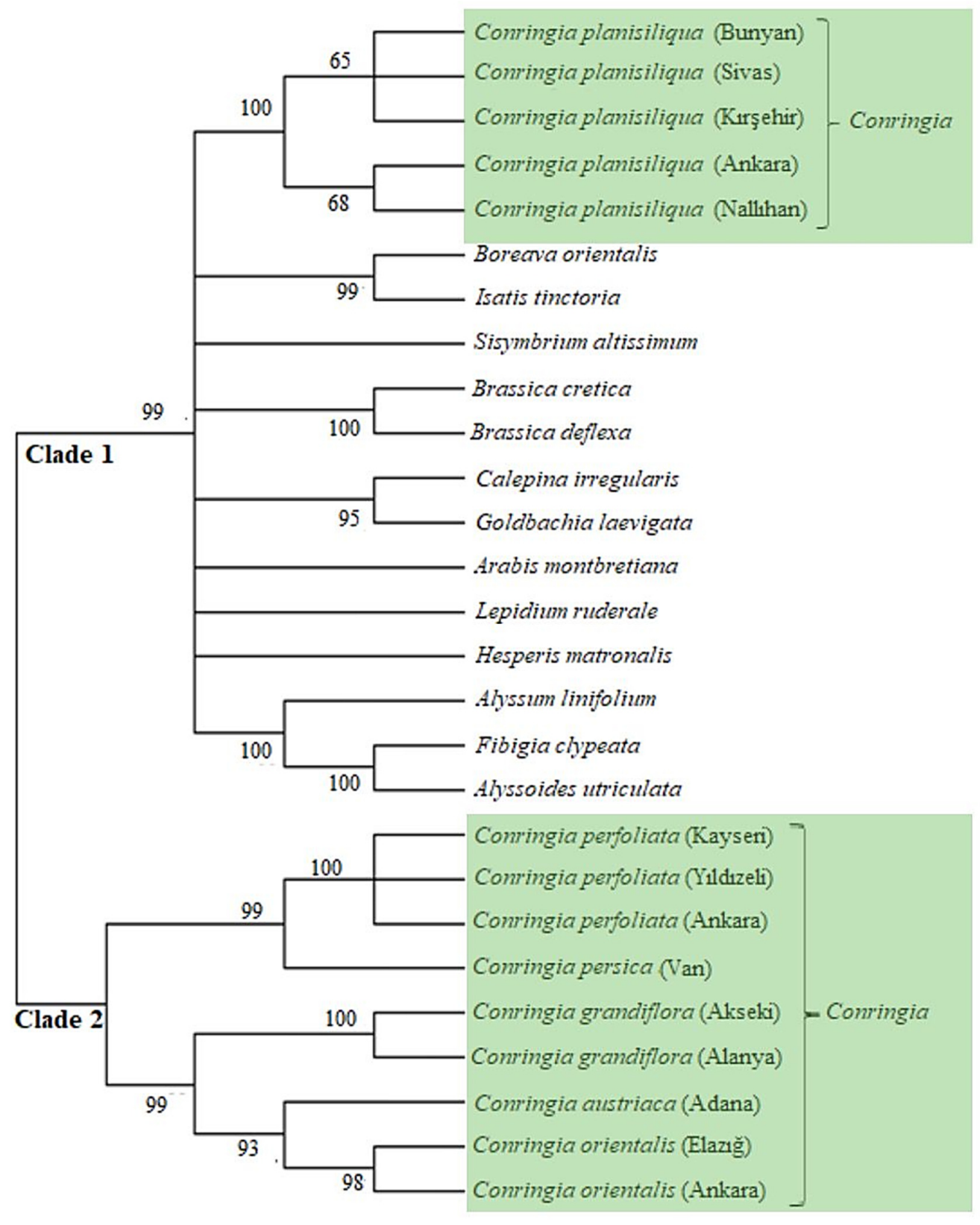

Figure 3. The Neighbour joining tree generated using nrITS sequences Conringia genus and other Brassicaceae species sequences retrieved form NCBI (Bootstrap values greater than $50 \%$ are given above branches) 


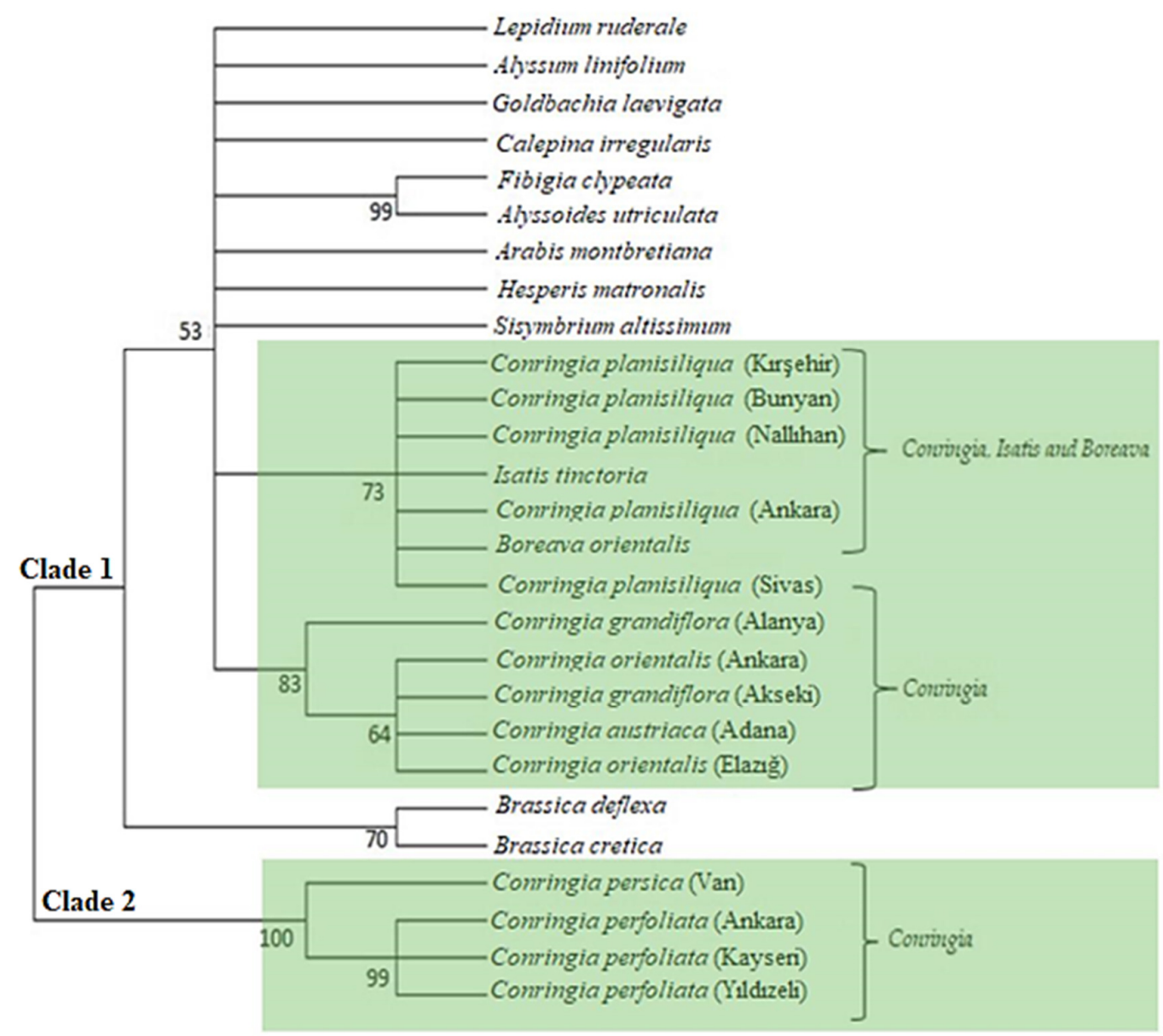

Figure 4. The Neighbor joining tree generated using trnL-F sequences Conringia genus and other Brassicaceae species sequences retrieved form NCBI (Bootstrap values greater than $50 \%$ are given above branches)

\section{Conclusions}

In this study, phylogenetic analysis was performed using nrITS and trnL-F sequences to elucidate the phylogenetic relationships of Turkish Conringia taxa. In trees generated with both the nrITS and trnL-F sequences, $C$. orientalis, $C$. grandiflora and $C$. austriaca appeared in the same group. However, while $C$. orientalis, $C$. grandiflora and $C$. austriaca were in separate clades (or sub-groups) in nrITS analyzes, $C$. perfoliata and C. persica appeared in the same clade in $t r n \mathrm{~L}-\mathrm{F}$ results. Results obtained with other Brassicaceae species have revealed that the Conringia is polyphyletic, C. planisiliqua coexists with Boreava orientalis and Isatis tinctoria, and these findings are supported by previous studies.

\section{Authors' Contributions}

M.Y.P: collected plant species. Molecular and data analysis was done by M.A and E.S. The manuscript was drafted by E.S. and reviewed by all the authors before the submission.

All authors read and approved the final manuscript. 
Sevindik E et al. (2021). Not Sci Biol 13(3):11034

\section{Acknowledgements}

This research was supported by the Aydın Adnan Menderes Universtiy ([grant number (ZRF19034).

\section{Conflict of Interests}

The authors declare that there are no conflicts of interest related to this article.

\section{References}

Ahmed NU, Park JI Kim HR, Nou IS Nou (2012). Progress in genetic manipulation of the Brassicaceae. Journal of Plant Biotechnology 39(1):1-12. http://dx.doi.org/10.5010/JPB.2012.39.1.001

Al-Shehbaz IA, Mutlu, B, Dönmez AA 2007. The Brassicaceae (Cruciferae) of Turkey, updated. Turkish Journal of Botany 31(4):327-336.

Bulbul AS, Kader Varlik MA, Arslan A (2019). Fruits, seeds and pollen morphology of Alyssum L. (Brassicaceae) and their taxonomic value. Fresenius Environmental Bulletin 28(3):2199-2219.

Bulbul AS, Varlik K, Armagan M (2018). Taxonomic implication of trichomes on silicules in Alyssum L. (Brassicaceae) species in Turkey. Fresenius Environmental Bulletin 27(12B): 9581-9589.

Couvreur TL, Franzke A, Al-Shehbaz A., Bakker FT, Koch MA, Mummenhoff K (2010). Molecular phylogenetics, temporal diversification, and principles of evolution in the mustard family (Brassicaceae). Molecular Biology and Evolution 27(1):55-71. https://doi.org/10.1093/molbev/msp202

Demir I, Kaya İ, Usta M, Sipahioğlu HM (2020). Molecular phylogeny based on its sequences of nrDNA of some species belonging to dodder (Cuscuta L.) genus from various ecological sites of Turkey. Notulae Botanicae Horti Agrobotanici Cluj-Napoca 48(3):1332-1340. https://doi.org/10.15835/NBHA48311997

Dönmez AA, Aydın ZU, Wang X (2021). Wild Brassica and its close relatives in Turkey, the genetic treasures. Horticultural Plant Journal 7(2):97-107. https://doi.org/10.1016/j.hpj.2020.11.003

Drabkova L, Kirschner J, Vlček Č, Pačes V (2004). TrnL-trnF intergenic spacer and trnL intron define major clades within Luzula and Juncus (Juncaceae): importance of structural mutations. Journal of Molecular Evolution 59(1):1-10. https://doi.org/10.1007/s00239-004-2598-7

Felsenstein J (1985). Confidence limits on phylogenies: an approach using the bootstrap. Evolution 39:783-791. https://doi.org/10.1111/j.1558-5646.1985.tb00420.

Filiz E, Uras ME, Ozyigit II, Sen U, Gungor H (2018). Genetic diversity and phylogenetic analyses of Turkish rice varieties revealed by ISSR markers and chloroplast trnl-F region. Fresenius Environmental Bulletin 27(12):8351-8358.

Gidik B, Gül V, Sefali A (2019). A study of wild plant species of Brassicaceae family in Bayburt region of Turkey. Pakistan Journal of Botany 51(2):681-687.

Guo GY, Chen F, Shi XD, Tian YS, Yu M Q, Han XQ, ... Zhang Y (2016). Genetic variation and phylogenetic relationship analysis of Jatropha curcas L. inferred from nrDNA ITS sequences. Comptes Rendus Biologies 339(9-10):337-346. https://doi.org/10.1016/j.crvi.2016.06.004

Hall TA (1999). BioEdit: a user-friendly biological sequence alignment editor and analyses program for Windows 95/98/NT. Nucleic Acids Symposium 41:95-98.

Hedge IC (1965). Conringia adans. In: Davis PH (Ed). Flora of Turkey and the East Aegean Island, Vol 1, 275-279, Edinburgh University Press. Edinburgh.

Kaya E, Vatansever R, Filiz E (2018). Assessment of the genetic relationship of Turkish olives (Olea europaea subsp. europaea) cultivars based on cpDNA trnL-F regions. Acta Botanica Croatica 77(1):88-92. https://doi.org/10.1515/botcro-2017-0019

Kawarty AMA., Behçet L, Çakilcioğlu U (2020). An ethnobotanical survey of medicinal plants in Ballakayati (Erbil, North Iraq). Turkish Journal of Botany 44(3):345-357. https://doi.org/10.3906/bot-1910-39

Khan G, Zhang FQ, Gao QB, Fu PC, Xing R, Wang JL, ... Chen SL (2016). Phylogenetic reconstruction between the old and new world spiroides inferred from plastid trnL-F and nrDNA its sequences. Pakistan Journal of Botany 48(6):2399-2407. 
Khosravi A R, Mohsenzadeh S, Mummenhoff K (2009). Phylogenetic relationships of Old World Brassicaceae from Iran based on nuclear ribosomal DNA sequences. Biochemical Systematics and Ecology 37(2):106-115. https://doi.org/10.1016/j.bse.2009.01.010

Koch M, Haubold B, Mitchell-Olds T (2001). Molecular systematics of the Brassicaceae: evidence from coding plastidic matK and nuclear Chs sequences. American Journal of Botany 88(3):534-544. https://doi.org/10.2307/2657117

Koch MA, Dobeš C, Kiefer C, Schmickl R, Klimeš L, Lysak MA (2007). Super network identifies multiple events of plastid $\operatorname{trnF}$ (GAA) pseudogene evolution in the Brassicaceae. Molecular Biology and Evolution 24(1):63-73. https://doi.org/10.1093/molbev/msl130

Liu L, Zhao B, Tan D, Wang J (2012). Phylogenetic relationships of Brassicaceae species based on matK sequences. Pakistan Journal of Botany 44(2):619-626.

Najarian F, Sheidai M, Koohdar F, Talebi SM (2020). Molecular phylogeny of the sect. Adonıs (Genus Adonis L., Ranunculaceae). Genetika. 52(3):1075-1086. https://doi.org/10.2298/GENSR2003075N

Özüdoğru B, Al-Shehbaz IA, Mummenhoff K (2017). Tribal assignment of Heldreichia Boiss. (Brassicaceae): evidence from nuclear ITS and plastidic ndhF markers. Plant Systematics and Evolution 303(3):329-335. https://doi.org/10.1007/s00606-016-1374-7

Penjor T, Anai T, Nagano Y, Matsumoto R, Yamamoto M (2010). Phylogenetic relationships of Citrus and its relatives based on $r b c L$ gene sequences. Tree Genetics \& Genomes 6(6):931-939. https://doi.org/10.1007/s11295-0100302-1

Polat R, Güner B, Yüce Babacan E, Çakılcığlu U (2017). Survey of wild food plants for human consumption in Bingöl (Turkey). Indian Journal of Traditional Knowledge 16(3):378-384.

Poyraz I (2016). Comparison of ITS, RAPD and ISSR from DNA-based genetic diversity techniques. Comptes Rendus Biologies 339(5-6):171-178. https://doi.org/10.1016/j.crvi.2016.04.001

Saitou N, Nei M (1987). The neighbor-joining method: a new method for reconstructing phylogenetic trees. Molecular Phylogenetic and Evolution 4(4):406-425. https://doi.org/10.1093/oxfordjournals.molbev.a040454

Selvi S, Aladi HI, Paksoy MY (2019). Micromorphological and anatomical investigations on Conringia Heist. Ex Fabr. Bangladesh Journal of Botany 48(4):1153-1162. https://doi.org/10.3329/bjb.v48i4.49071

Sevindik E, Paksoy YM, Aydoğan M, Topseçer F (2020). Genetic variation and molecular relationships taxa of Conringia heist. ex Fabr (Brassicaceae) based on RAPD markers in Turkey. Genetika 52(1):107-114. https://doi.org/10.2298/GENSR2001107S

Sirali R, Uğur A, Zambi O, Dikmen A Çağlar S (2013). The importance of some species of Cruciferous (Brassicaceae) family for beekeeping Academic Journal of Agriculture 2(2):107-115.

Sun YL, Lee HB, Kim NY, Park WG, Hong SK (2012). Genetic diversity of Kalopanax pictus populations in Korea based on the nrDNA ITS sequence. Journal of Plant Biotechnology 39(1):75-80. http://dx.doi.org/10.5010/JPB.2012.39.1.075

Taberlet PT, Gielly L, Pautou G, Bouvet J (1991). Universal primers for amplification of three non-coding regions of chloroplast DNA. Plant Molecular Biology 17:1105-1109. https://doi.org/10.1007/BF00037152

Tamura K, Stecher G, Peterson D, Filipski A, Kumar S (2013). MEGA6: Molecular evolutionary genetics analysis version 6.0. Molecular Biology and Evolution 30(12): 2725-2729. https://doi.org/10.1093/molbev/mst 197

Türktaş M, Aslay M, Kaya E, Ertuğrul F (2012). Molecular characterization of phylogenetic relationships in Fritillaria species inferred from chloroplast trnL-trnF sequences. Turkish Journal of Biology 36(5):552-560. https://doi.org/10.3906/biy-1201-30

Warwick SI, Sauder CA (2005). Phylogeny of tribe Brassiceae (Brassicaceae) based on chloroplast restriction site polymorphisms and nuclear ribosomal internal transcribed spacer and chloroplast trnL intron sequences. Canadian Journal of Botany 83(5):467-483. https://doi.org/10.1139/b05-021

White TJ, Bruns T, Lee S, Taylor J (1990). Amplifications and direct sequencing of fungal ribosomal RNA genes for phylogenetics. In: PCR protocols: a guide to methods and applications. Innis M, Gelfand D, Sninsky J, White T (Ed). Academic Press, San Diego, California, USA, pp315-322.

Yilmaz-Çitak B, Dural H (2020). Fruit and seed micromorphology of the genus Iberis L. (Brassicaceae) in Turkey and its utility in taxonomic delimitation. Botanical Sciences 98(4):584-592. https://doi.org/10.17129/botsci.2573

Zhao B, Liu L, Tan D, Wang J (2010). Analysis of phylogenetic relationships of Brassicaceae species based on Chs sequences. Biochemical Systematics and Ecology 38(4):731-739. https://doi.org/10.1016/j.bse.2010.06.003 
OPEN ACCESS

(c) (i)

The journal offers free, immediate, and unrestricted access to peer-reviewed research and scholarly work. Users are allowed to read, download, copy, distribute, print, search, or link to the full texts of the articles, or use them for any other lawful purpose, without asking prior permission from the publisher or the author.

License - Articles published in Notulae Scientia Biologicae are Open-Access, distributed under the terms and conditions of the Creative Commons Attribution (CC BY 4.0) License.

( $)$ Articles by the authors; SHST, Cluj-Napoca, Romania. The journal allows the author(s) to hold the copyright/to retain publishing rights without restriction. 